\title{
Фитопатологический скрининг сортообразцов озимой пшеницы по возрастной устойчивости к основным грибным болезням
}

Ыскакова Г.Ш.*, РhD-докторант, м.н.с., Молдажанова Р.А., магистр, м.н.с., Мауленбай А.Д., магистр, м.н.с., Рсалиев А.С., к.с.-х.н., заведуюший лабораторией.

Научно-исследовательский институт проблем биологической безопасности, Гвардейский, Казахстан

*e-mail: y_gulbahar@mail.ru

В 2019 году на искусственном инфекиионном фоне видов ржавчины и на естественном фоне желтой пятнистости листьев охарактеризованы 481 сорта, образцы и линии пшенищы Казахстана, ближнего и дальнего зарубежья. По результатам фитопатологической оценки среди сортообразиов пшеницы отобраны источники полевой устойчивости к основным грибным болезням. Выявлено 145 источников озимой пшеницы с высокой устойчивостью к возбудителю желтой ржавчины, 253 - листовой ржавчины, 171 - стеблевой ржсавчины, 71 -желтой пятнистости листьев.

Ключевые слова: пшеница, сортообразиьы, грибные болезни, устойчивость, восприимчивость.

\section{Phytopatological screening of winter wheat varieties in adult plant resistance to major fungi diseases}

Yskakova G.Sh., PhD-student, junior researcher, Moldazhananova R.A., M.S., junior researcher, Maulenbay A.D., M.S., junior researcher, Rsaliyev A.S., PhD, head of laboratory Research Institute for Biological Safety Problems, Gvardeiskiy,ZZhambylskaya Oblast, Kazakhstan.E-mail:y_gulbahar@mail.ru

In 2019, 481 varieties, samples and wheat lines from Kazakhstan and abroad were characterized on an artificial infectious background of rust types and on a natural background of tan spot. Sources of resistance to the main fungal diseases were selected according to the results of phytopathological assessment among the varieties of wheat. Study demonstrated overall 145 sources of winter wheat with resistance to the causative agent of yellow rust, 253 - leaf rust, 171 stem rust, and 71 - tan spot.

Key words: wheat, varietal samples, fungal diseases, resistance, susceptibility.

В Казахстане на посевах озимой пшеницы ежегодно развивается не одна, а комплекс болезней, вызывающих значительные потери урожая. 
Среди болезней пшеницы наиболее распространенными и вредоносными являются виды ржавчины и пятнистости листьев. Они относятся к особо опасным болезням, создающим большой риск для продовольственной безопасности республики. Многие допущенные к использованию в Казахстане сорта озимой пшеницы восприимчивы к указанным патогенам $[1,2]$. Скрининг генофонда пшеницы к грибным болезням создает предпосылки для выведения и внедрения в производство новых болезнеустойчивых сортов пшеницы, которые являются основой интенсификации сельского хозяйства. В связи с этим выявление сортов озимой пшеницы с высокой устойчивостью к болезням является весьма актуальной задачей, имеющей не только научную, но и практическую значимость в селекции пшеницы.

Целью данной работы являлось фитопатологический скрининг сортообразцов озимой пшеницы по возрастной устойчивости к основным грибным болезням.

В 2019 году на искусственном инфекционном фоне видов ржавчины и на естественном фоне желтой пятнистости листьев охарактеризованы 481 линии, сорта и образцы пшеницы Казахстана, ближнего и дальнего зарубежья. Полевые опыты заложены в полевом орошаемом участке НИИПББ. Для накопления и распространения инфекции в питомнике, между ярусами, посеяли восприимчивые сорта-спредеры, в качестве которых служили Morocco и Богарная 56. Весной, в фазе кущения, посевы озимой пшеницы заражали урединиоспорами видов ржавчины. Для заражяения использовали только местную популяцию грибов, либо смесь изолятов с определенной вирулентностью. Инфекционный материал на растения наносили методом опрыскивания водной суспензией спор с 0,001 \% Твин 80 [3]. Учет пораженности растений проводили в период максимального развития заболеваний на восприимчивых контрольных сортах пшеницы. Степень поражения ржавчинными болезнями (в \%) оценивали по шкале R.F. Peterson и др. [4]. Степень устойчивости и восприимчивости образцов пшеницы к пятнистости листьев устанавливали по шкале Saari, Prescott [5].

В 2019 году на экспериментальном полевом участке изучены устойчивости 68 коммерческих сортов озимой пшеницы Центральной Азии и Закавказья (ЦАЗ), 20 элитных и 80 перспективных линий, а также зарубежные питомники IWWYT-IR (208 образцов) и IWWYT-SA (105) к трем видам ржавчины и желтой пятнистости. На основе анализа полученных данных, сортобразцы озимой пшеницы сгруппированы по степени поражения болезнями (рисунок). 

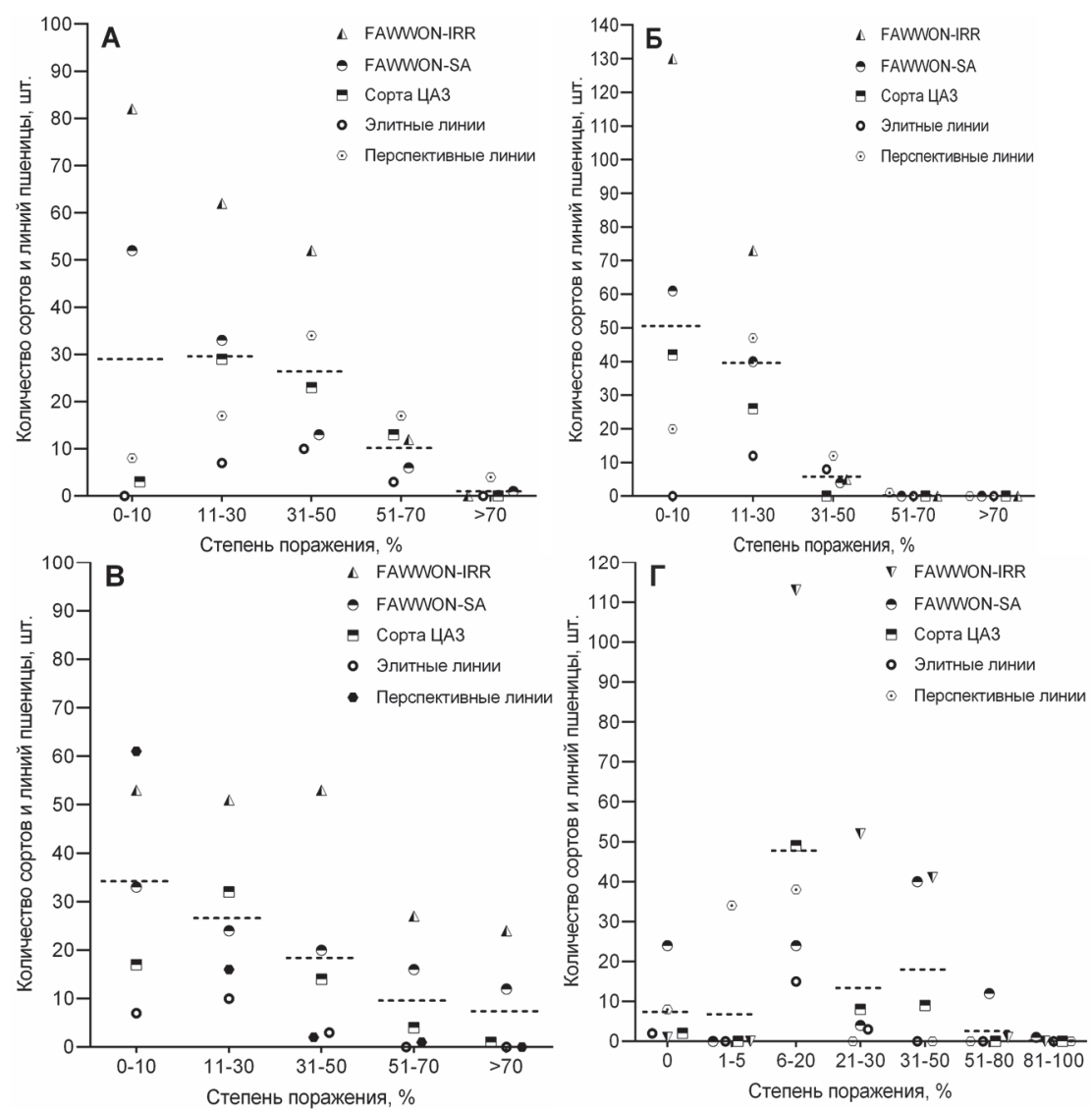

Распределение сортообразцов озимой пшеницы по степени поражения желтой (А), листовой (Б), стеблевой ржавчиной (В) и желтой пятнистости (Г)

Погодные условия вегетационного сезона 2019 года складывались благоприятно для развития желтой ржавчины, в связи, с чем патоген развивался в сильной степени в изученных питомниках озимой пшеницы. К желтой ржавчине высокую устойчивость показывают всего 145 сортообразцов (30,1 \% от числа испытанных), остальные характеризуются разным уровнем устойчивости и восприимчивости (рисунок, А). Максимальная доля устойчивых к патогену образцов озимой пшеницы в изученной выборке приходилась на зарубежные образцы в питомниках FAWWON-IRR (82) и FAWWONSA (52).

В 2019 году листовая ржавчина на озимой пшенице проявилась 
поздно, и ее развитие было в слабой степени. Первые пустулы гриба выявлены на изученных материалах только в фазе колошения. В зависимости от питомников и сортовых особенностей поражение листовой ржавчиной листьев среднего и верхнего ярусов в период налива зерна колебалось от 0-5 до 20-60\%. При этом во всех изученных питомниках только 30 образцов были восприимчивыми, а остальные оказались устойчивыми и умеренно устойчивыми к болезни (рисунок, Б).

Оценка устойчивости озимой пшеницы к возбудителю стеблевой ржавчины в 2019 году показала, что более 35 \% (171 образец) из них проявляют устойчивость, когда растения находятся во взрослом состоянии. Сравнительно слабое развитие патогена отмечено на элитных и перспективных линиях озимой пшеницы (рисунок, В).

Установлено, что большинство изученных селекционных материалов озимой пшеницы поражаются в средней и сильной степени желтой пятнистости. В полевых условиях всего обнаружено 37 сортообразцов озимой пшеницы с иммунной реакцией к желтой пятнистости. Результаты оценки показали высокую устойчивость 34 образцов с поражением до 5 \% (рисунок, Г).

Таким образом, в 2019 году дана характеристика сортов, образцов и линий озимой мягкой пшеницы (в общей сложности 481) по возрастной устойчивости к основным грибным болезням. На основе анализа полевых данных отобран всего 171 источник озимой пшеницы с устойчивостью к возбудителю стеблевой ржавчины, 145 - желтой ржавчины, 253 - листовой ржавчины и 71 - желтой пятнистости.

Благодарности: Работа была выполнена при финансовой поддержке Министерства сельского хозяйства Республики Казахстан в рамках программно-целевого финансирования на 2018-2020 гг. (ИРН BR06249329).

\section{Список литературь}

1. Койшыбаев М. Болезни пшеницы. - Анкара: ФАО, 2018. - 365 с.

2. Рсалиев А.С. Выявление доноров устойчивости мягкой пшеницы к желтой ржавчине / А.С. Рсалиев, Г.Ш. Ыскакова, Н.Т. Амирханова, Ж.У. Пахратдинова // Вестник КазНУ, серия биологическая, 2015. №3 (65). - С.150-160.

3. Гешеле Э.Э. Методы заражения растений и учета его результатов в селекции / Э.Э. Гешеле // Основы фитопатологической оценки в селекции растений. Москва: Колос, 1978. - С.129-159.

4. Peterson R.F. A diagrammatic scale for estimating rust intensity on leaves and stems of cereals / R.F. Peterson, A.B. Campbell, A.E. Hannah // Canad. J. Res., 1948. V.26. - P.496-500.

5. Saari, E.E. A scale for appraising the foliar intensity of wheat diseases / E.E. Saari, J.M. Prescott // Plant Dis.Rep., 1975. - V.59. - P. 377-380. 